\title{
KAJIAN SIFAT MAGNETIK DARI PASIR BESI PANTAI LOGENDING KABUPATEN KEBUMEN
}

\author{
Bilalodin \\ Program Studi Fisika, Jurusan MIPA Fakultas Sains dan Teknik \\ Universitas Jenderal Soedirman Purwokerto \\ Email: bilalodin.unsoed@gmail.com
}

\begin{abstract}
Study on magnetic properties of iron sand on the Logending beach sand has been done. The research aims to identify the mineral content and characterization of magnetic properties on the Logending beach sand. The irond sand samples taken from the Logending beach with several lokation. Sand then dried, determined density and magnetic content is separated using a permanen magnet. The iron sand were analyzed using XRD ( $\mathrm{X}$-ray difraction) and characterization of magnetic properties using the VSM (Vibrating sample magnetometer). The research shows that minerals are contained hematit $\left(\mathrm{Fe}_{2} \mathrm{O}_{3}\right)$, with a value of susceptibility is $0.43 \times 10-6 \mathrm{~m}^{3} / \mathrm{kg}$. The main magnetic mineral of iron sand from logending beach is paramagnetic.
\end{abstract}

Keywords: Iron sand, mineral magnetic, susceptibility. XRD, VSM

\section{PENDAHULUAN}

Pasir besi hingga saat ini hanya digunakan sebagai bahan pendukung pada pembangunan fisik seperti gedung, jembatan, perumahan, dan jalan raya. Menurut Zulkarnain (2000) pasir besi mengandung bahan magnet yang merupakan material yang dapat diaplikasikan untuk pengembangan industri otomotif, elektronika, komputasi sampai peralatan rumah tangga. Pasir besi juga sebagai salah satu bahan baku utama dalam industri baja dan industri alat berat (Yulianto, dkk., 2003).

Potensi dan sebaran pasir besi di Indonesia banyak di jumpai di berbagai pulau mulai Pantai Barat Sumatera, Kalimantan, Sulawesi, kawasan Nusatenggara, Kepulauan Maluku dan Pantai Selatan Jawa. Kegiatan eksplorasi dan inventarisasi berkaitan dengan endapan besi tersebut sejauh ini belum dilakukan secara menyeluruh, dan sistimatis sehingga belum dapat dimanfaatkan secara optimal (Mufit, dkk., 2006).
Salah satu potensi endapan besi (pasir besi) yang dijumpai di kepulauan Indonesia diantaranya terdapat di Pantai Selatan Logending Kebumen Jawa Tengah. Nilai ekonomi pasir pantai di wilayah Pantai Selatan Logending supaya dapat meningkat maka diperlukan adanya karakterisasi kandungan mineral untuk mengungkap mineral-mineral yang berpotensi tinggi dan mengetahui sifat dan karakteristik mineral magnetik penyusunnya. Kandungan mineral dan sifat magnetik pasir besi yang potensial diharapkan dapat dimanfaatkan untuk kepentingan industri.

\section{METODE PENELITIAN}

\section{Bahan dan Alat}

Bahan yang digunakan pada penelitian adalah pasir besi Pantai Logending daerah Kabupaten Kebumen. Peralatan yang digunakan diantaranya: magnet, wadah sampel, skop, plastik, neraca digital, seperangkat alat X-Ray Diffraction dan seperangkat alat VSM (Vibrating Sample Magnetometer). 


\section{Prosedur Penelitian}

Contoh bahan pasir besi pada studi ini diambil dari 6 lokasi di Pantai Logending Kabupaten Kebumen . Pasir ini berwarna kehitaman dalam keadaan alamiah. Bahan magnetik dari bahan alam aslinya dipisahkan dengan menggunakan metode ektraksi .menjadi serbuk yang halus dan ditempatkan pada wadah yang lebar. Sebuah magnet permanen yang kuat dan dilapisi plastik dimasukkan dalam wadah. Serbuk yang menempel pada magnet kemudian diambil dan dipisahkan (Gambar 1). Sebagian serbuk halus hasil ektraksi dianalisis jenis mineralnya dengan metode difraksi sinar $\mathrm{X}$, sedangkan karakteristik magnetik mengggunakan VSM (Yulianto,dkk., 2003).

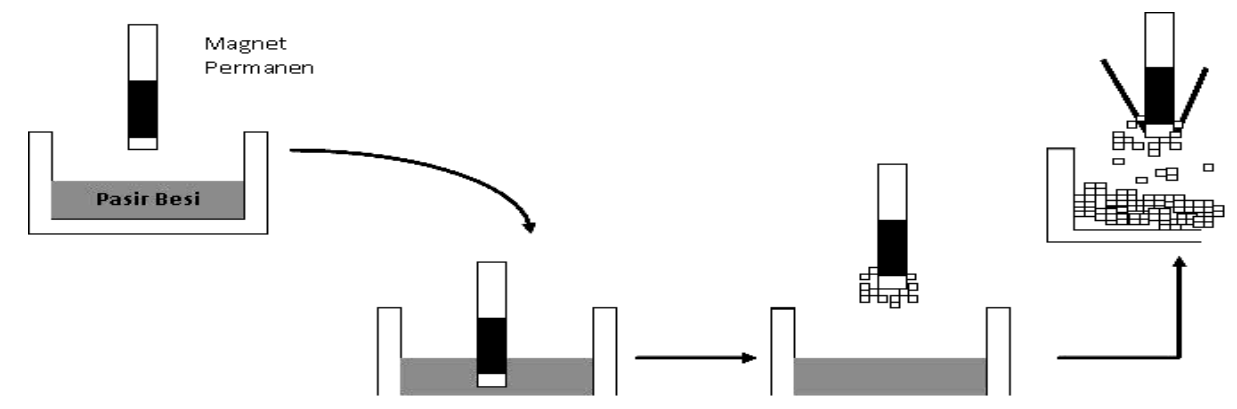

Gambar 1. Proses ektraksi mineral magnetik dari pasir besi dengan menggunakan magnet permanen.

\section{HASIL DAN PEMBAHASAN}

Rata-rata kandungan mineral magnetik pada pasir besi yang dimbil dari Pantai Logending adalah sebesar $4,05 \%$. Berdasarkan data tersebut jumlah kandungan mineral magnetik lebih kecil dibandingkan material non magnetik. Hasil uji XRD pada Gambar 2 menunjukkan bahwa kandungan mineral magnetik penyusun pasir besi di Pantai Logending pada umumnya adalah hematit $\left(\mathrm{Fe}_{2} \mathrm{O}_{3}\right)$. Hasil yang diperoleh sama dengan yang diperoleh oleh Eka, dkk. (2000) pada pasir mineral.

Berdasarkan hasil karakterisasi sampel pasir besi menggunakan VSM (Vibrating Sample Magnetometer) (Gambar 3) diperoleh kurva histerisis hubungan medan magnet (Tesla) versus magnetisasi (emu/gram) pada temperatur $293,7{ }^{\circ} \mathrm{K}$. Karakteristik kurva histerisis pasir berbentuk kurva menyempit ke sumbu momen magnetik dengan nilai magnetisasi yang kecil. Hasil karakterisasi VSM pada sampel pasir besi Pantai Logending saat diberikan medan magnet awal $(\bar{H})$ sebesar 0,0001 Tesla menghasilkan magnetisasi $(\bar{M})$ sebesar 3,032607 emu/gr. Pada saat diberikan medan magnet maksimum $\left(\mathrm{H}_{\text {maks }}\right)$ sebesar 0,9983 Tesla menghasilkan magnetisasi maksimum $\left(\mathrm{M}_{\text {maks }}\right)$ sebesar 39,48641 emu/gr dan magnetisasi remanen $\left(\mathrm{M}_{\mathrm{r}}\right)$ sebesar 7,08969387 emu/gr. 


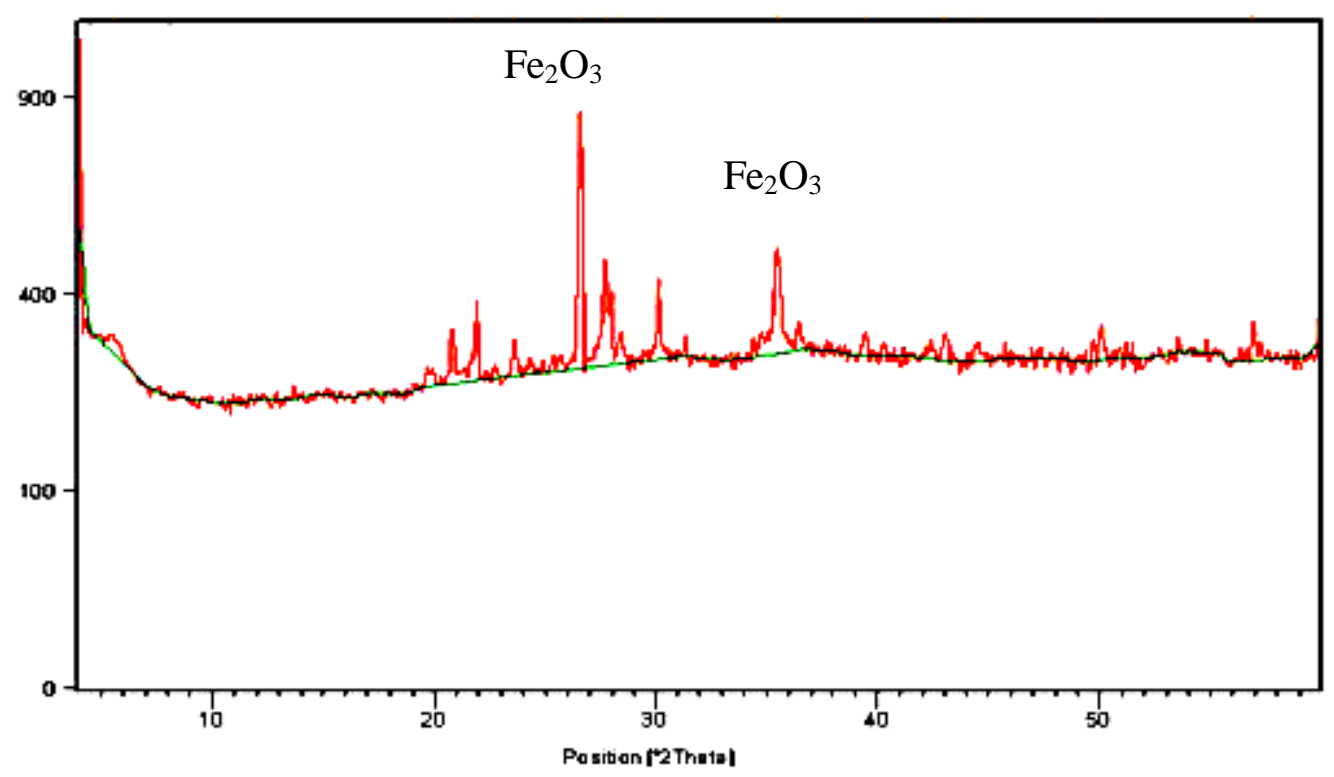

Gambar 2. Pola difraksi sinar X bagi mineral yang telah diektraksi secara magnetik dari pasir besi Pantai Logending.

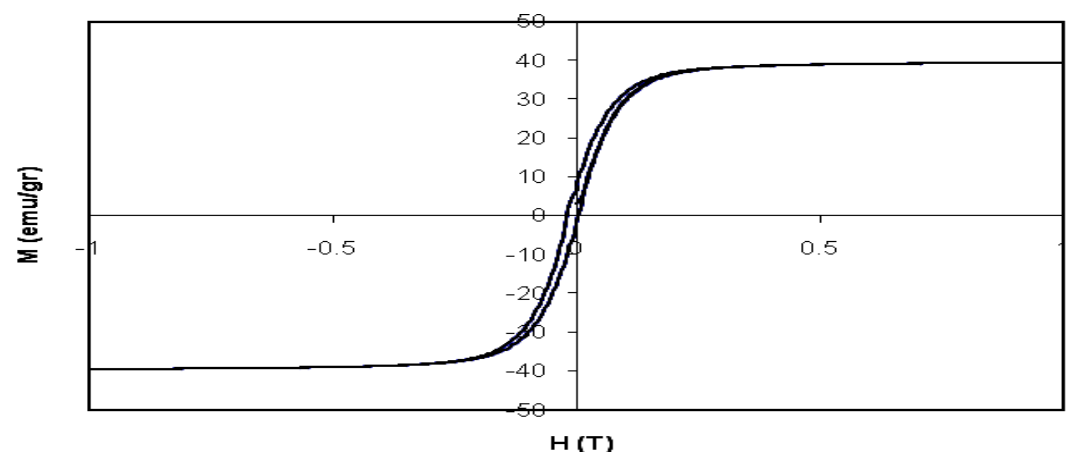

Gambar 3 Karakteristik kurva histerisis pasir besi Pantai Logending

Hasil perhitungan nilai suseptibilitas magnetik dari pasir besi Pantai Logending Kabupaten Kebumen diperoleh $0,28 \times 10^{-6} \mathrm{~m}^{3} / \mathrm{kg}$. Nilai suseptibilitas tersebut termasuk dalam selang nilai suseptibilitas dari mineral hematit $\left(a-\mathrm{Fe}_{2} \mathrm{O}_{3}\right)$ yaitu $0,1 \times 10^{-6} \mathrm{~m}^{3} / \mathrm{kg}$ $\mathrm{s} / \mathrm{d} 7,6 \times 10^{-6} \mathrm{~m}^{3} / \mathrm{kg}$ (Hunt, dkk., 1995). Hasil nilai suseptibilitas pasir besi Pantai Logending yang terhitung lebih rendah dari nilai suseptibilitas pasir besi Pantai Cilacap yaitu $2,85 \times 10^{-4} \mathrm{~m}^{3} / \mathrm{kg}$. Perbedaan ini diduga karena rendahnya kandungan besi dalam oksida $\mathrm{Fe}_{2} \mathrm{O}_{3}$. Nilai suseptibilitas menunjukkan bahwa mineral magnetik pasir besi Pantai Logending masuk dalam kategori paramagnetik karena memiliki nilai supseptilitas yang lebih keci dari 1 .

\section{KESIMPULAN}

Berdasarkan hasil penelitian maka diperoleh kesimpulan bahwa nilai suseptibilitas mineral magnetik pasir besi Pantai Logending Kabupaten Kebumen termasuk dalam sifat paramagnetik. Jenis mineral magnetik yang terkandung pada pasir besi di Pantai Logending adalah hematit $\left(\mathrm{Fe}_{2} \mathrm{O}_{3}\right)$ dengan kadar mineral magnetik sekitar $4,05 \%$. 
DAFTAR PUSTAKA

Zulkarnain. 2000. Kemungkinan

Pemanfaatan Pasir Besi Pesisir Pantai Aceh untuk Fabrikasi Magnet. Proseding Seminar Nasional Bahan Magnet I Serpong.

Yulianto, A., Bijaksana S,dan Loeksmanto W,. 2003. Comperatif Study on Magnetic Characterization od Iron Sand from Severala Location in Central Java. Indonesion journal of Physisc Vol. 14 p.63-66.

Mufit, F., F, Amir, dan S, Bijaksana. 2006. Kajian tentang Sifat Magnetik Pasir Besi dari Pantai Sunur Pariaman Sumatera Barat. Jurnal Geofisika. Vol 1, pp 2-5.
Yulianto, A, Bijaksana, S dan Loeksmanto, W. 2002. Karakterisasi Magnetik dari Pasir Besi Cilacap. Jurnal Fisika Himpunan Mahasiswa Fisika Indonesia. Vol A5, pp 1-4

Eka, D., C, N, A, Manaf dan B, Budi 2000. Indentifikasi Kandungan Senyawa Kimia Pada Pasir Mineral. Proseding Seminar Nasional Bahan Magnet I, Serpong.

Hunt,C, P., B, M, Moskowitz and K, Banerji. 1995. Rosk Physisc and Phase Relation: Hand books of Physiscal Constants. American Geophysiscal Union, Washington. 